\title{
Tampilan Pengantrian Pada Ruang Ganti Di Department Store
}

\author{
Edo Anggoro ${ }^{1}$, Dali Santun Naga ${ }^{2}$, Meirista Wulandari ${ }^{1}$
}

\begin{abstract}
Advanced technologies increase business value then contribute more cosiness for customer [1]. Based on technologies advancement, a smartphone android can be designed as user interface in department store to make their customer more comfort and convenience. Customer needs to try on some clothes before they buy them. User interface via monitor in smartphone android can support customer to know the empty fitting room conveniently. A sensor was placed in fitting room to detect a movement. This detection is used as a sign if there is a person inside it. This sensor priority is to give an information about an empty fitting room and automatically technology. There is one additional feature about help button. It will be active if customer inside fitting room needs a clerk to help him. Some conditions are tested to know how successful the system is. There are 12 conditions for each fitting room or all (4) fitting rooms. The results show that detection sensor can connect to android system in smartphone, help button can connect with LED to show the sign that customer needs clerk to help him and the connection between microcontroller with smartphone can be done by bluetooth to show the entire system works. Keyword: Android, Bluetooth, LED, Fitting Room.
\end{abstract}

\begin{abstract}
ABSTRAK: Kecanggihan teknologi membawa nilai bisnis meningkat sehingga memberikan kenyamanan bagi pelanggan [1]. Berdasarkan kemajuan teknologi tersebut, sebuah smartphone android dapat dimanfaatkan sebagai user interface dalam department store bagi pelanggan agar merasa lebih nyaman. User interface melalui layar monitor pada smartphone android dapat membantu pelanggan mengetahui letak ruang ganti yang kosong secara lebih nyaman. Sebuah sensor diletakan di ruang ganti. Sensor ini dapat mendeteksi seseorang yang masuk ke ruang ganti berdasar pada gerakan. Penggunaan sensor ini mengutamakan informasi ruangan yang kosong dan teknologi otomatis. Terdapat sebuah fitur tentang tombol bantuan. Tombol bantuan ini aktif bila pelanggan membutuhkan pramuniaga department store untuk membantunya. Beberapa kondisi dilakukan untuk menguji keberhasilan sistem ini. Sebanyak 12 kondisi diuji baik untuk masing-masing ruang ganti dan keseluruhan (4 buah) ruang ganti. Hasil dari pengujian didapatkan bahwa sensor pendeteksi gerakan dapat dihubungkan dengan android, tombol bantuan dapat dihubungkan dengan LED dan hubungan antara rangkaian sensor, tombol dan monitor dapat dilakukan melalui Bluetooth.
\end{abstract}

Kata kunci: Android, Bluetooth, LED, Ruang Ganti

\section{PENDAHULUAN}

$\mathrm{S}$ ebelum melakukan transaksi di suatu department store, pelanggan biasanya mencoba pakaian di ruang ganti. Ruang ganti pada umumnya berbentuk seperti ruangan kecil yang hanya menyediakan cermin seluruh badan dan gantungan pakaian. Dalam suatu department store, pelanggan yang mencoba pakaian harus menunggu giliran untuk kemudian diarahkan oleh pegawai ketika ada ruang ganti yang kosong. Namun, pegawai yang melakukan pengarahan tidak selalu mengetahui posisi ruang ganti yang kosong. Hal ini membuat pelanggan tidak mengetahui lokasi tersebut dengan mudah. Maka itu dibuat suatu pendeteksi keberadaan seseorang dengan memanfaatkan sensor di dalam ruang ganti. Pendeteksi tersebut membantu pelanggan untuk mengetahui lokasi ruang ganti yang kosong dengan mudah.

Kemudahannya dimaksud adalah keluaran hasil sensor pendeteksi dihubungkan dengan suatu tampilan, kecanggihan teknologi membawa nilai bisnis meningkat sehingga memberikan kenyamanan bagi pelanggan [1]. Sebuah tampilan user interface dapat dirancang untuk kemudahan dalam suatu department store dengan penerapan kemajuan teknologi. Dalam suatu department store, pelanggan perlu mengetahui ruang ganti yang kosong untuk mencoba pakaian yang dibelinya. Dengan tampilan user interface memberikan kenyamanan bagi pelanggan. Sebuah sensor diletakan di ruang ganti. Sensor ini dapat mendeteksi seseorang yang masuk ke ruang ganti berdasar pada gerakan. Penggunaan sensor ini mengutamakan informasi ruangan yang kosong dan teknologi otomatis [3]. Pelanggan dapat mengetahui ruangan yang kosong melalui tampilan user interface yang tersedia di depan ruang ganti tersebut. Rancangan user interface serupa telah diterapkan, salah satunya pada lahan parkir. Sebuah user interface dirancang untuk memudahkan pengendara mobil mengetahui tempat parkir. Sistem ini mampu menampilkan ketersediaan dari area yang kosong yang ditampilkan pada display [2].

Pelanggan yang datang ke department store memiliki kesulitan seperti salah mencoba ukuran pakaian. Kesulitan tersebut dapat teratasi jika ada pegawai yang dapat membantu pelanggan tersebut. Suatu fitur tombol bantuan dapat dikembangkan untuk menambah kenyamanan berbelanja di suatu department store.

Ketika dalam kondisi ramai, pelanggan harus mengantri untuk menggunakan ruang ganti tersebut. Pelanggan yang telah berada di dalam ruang ganti terkadang memerlukan bantuan pegawai dari department store. Bantuan yang biasa diperlukan pelanggan contohnya ketika ukuran pakaian yang ingin dicoba tidak sesuai dengan ukuran tubuh pelanggan, sehingga dengan bantuan ini pelanggan tidak perlu keluar dari ruang ganti dan mengantri lagi. Setiap ruang ganti terdapat tombol bantuan yang digunakan untuk memanggil pegawai department store tersebut. Lalu informasi modul pendeteksi gerak maupun tombol bantuan diproses oleh mikrokontroler sehingga dapat diketahui letak ruang ganti yang kosong dan dikirimkan ke tampilan user interface melalui modul bluetooth.

Sistem yang dirancang adalah pengantrian dan bantuan bagi pengguna ruang ganti di department store. Pengantrian ini menggunakan modul mikrokontroler yang dihubungkan dengan monitor sebagai tampilan user

\footnotetext{
${ }^{1}$ Program Studi Teknik Elektro, Fakultas Teknik, Universitas Tarumanagara

${ }^{2}$ Program Studi Teknik Informatika, Fakultas Sistem Informasi, Universitas Tarumanagara
} 
interface melalui modul bluetooth. Setiap ruang ganti mempunyai modul sensor dan tombol bantuan jika pelanggan membutuhkan bantuan dari pegawai department store tersebut.

Mikrokontroler terhubung oleh seluruh sensor, tombol, LED dan bluetooth. Modul bluetooth digunakan untuk mengirim informasi yang telah diproses dari mikrokontroler ke sebuah monitor sebagai tampilan user interface. Modul sensor mendeteksi keberadaan seseorang. Tombol bantuan yang ditekan oleh pelanggan memberikan informasi yang akan ditampilkan melalui modul Light Emitting Diode (LED). Pada tampilan user interface, keadaan lokasi ruang ganti akan ditampilkan dalam rupa indikator warna. Warna hijau menunjukkan lokasi ruang ganti yang kosong. Warna merah menunjukkan lokasi ruang ganti dalam keadaan terisi. Diagram blok sistem yang dirancang dapat dilihat pada Gambar 1. Dalam sistem ini digunakan 4 sensor untuk 4 ruangan, 4 tombol untuk 4 ruangan, dan 4 LED untuk 4 ruangan

\section{SENSOR PENDETEKSI GERAK DALAM RUANG GANTI}

Sensor merupakan sistem yang dapat digunakan untuk mendeteksi sesuatu dan berfungsi untuk mengukur besaran sesuatu [4].. Sistem yang dirancang menggunakan sensor gerak dan komponen yang digunakan dinamakan Passive Infrared Receiver (PIR) [5].

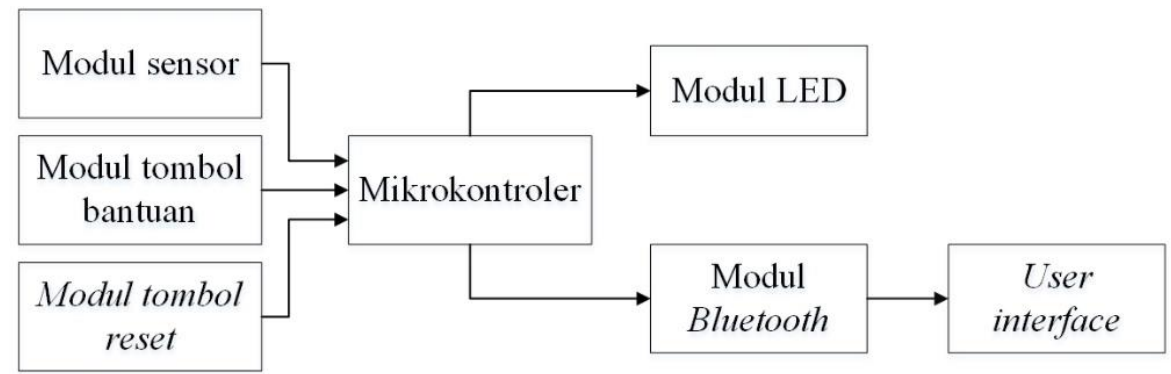

- Gambar 1. Diagram Blok Sistem yang Dirancang

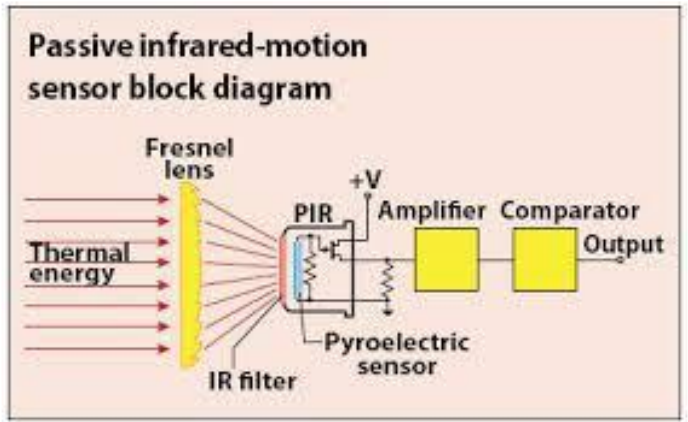

- Gambar 2. Sistem Kerja Passive Infrared Receiver

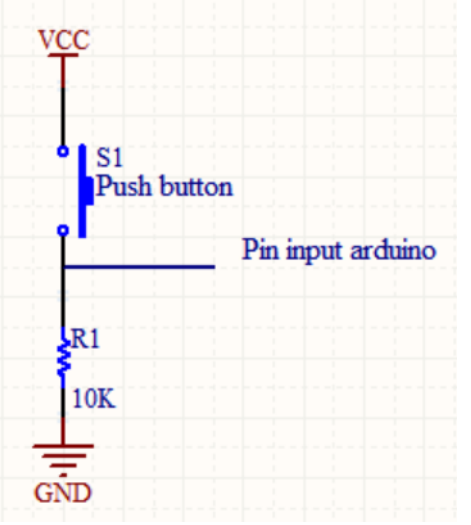

- Gambar 3. Skematik Rangkaian Modul Tombol

Sensor passive infrared receiver (PIR) HC-SR501 sebuah modul yang berfungsi untuk mendeteksi gerakan manusia di sekitar sensor dengan memanfaatkan teknologi infra merah (infrared). Tegangan kerja dari modul ini adalah 5V DC. Sensor PIR bersifat pasif, artinya sensor ini tidak memancarkan sinar inframerah tetapi hanya menerima radiasi sinar infra merah dari luar [6]. Sensor PIR terdiri dari beberapa bagian yaitu : Lensa Fresnel, Penyaring Infra Merah (Sensor), Sensor Pyroelectric (Sensor), Penguat Amplifier, Komparator. Pada umumnya 
sensor PIR memiliki jangkauan pembacaan efektif hingga 5 meter [5]. Sistem kerja passive infrared receiver dapat dilihat pada Gambar 2.

\section{PUSH-ON BUTTON}

Push-on button ini digunakan sebagai tombol bantuan ketika pelanggan ingin membutuhkan bantuan. Pegawai yang telah memberikan bantuan dapat menekan tombol reset.

Tombol tekan berfungsi sebagai saklar sederhana untuk menghubungkan atau memutuskan aliran arus listrik dengan sistem kerja tekan unlock (tidak mengunci). Sistem kerja unlock yaitu saklar akan bekerja saat penghubung atau pemutus aliran arus listrik saat tombol ditekan, dan saat tombol tidak ditekan (dilepas), maka saklar akan kembali pada kondisi normal.

Push-on button digunakan sebagai input dan dalam keadaan ditekan maka akan memberikan tegangan ke output yaitu pin input arduino. Skematik rangkaian modul tombol dapat dilihat pada Gambar 3.

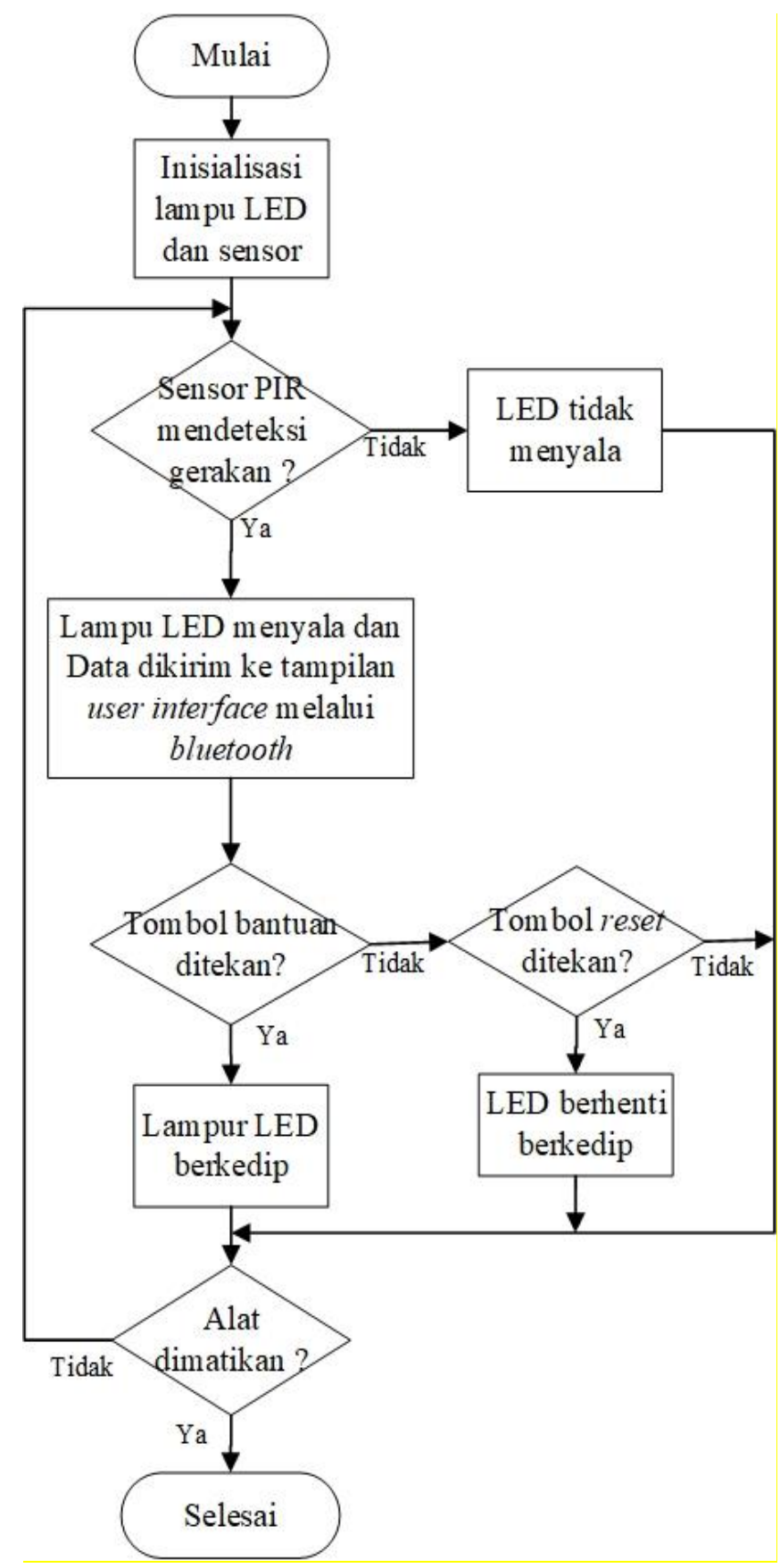

- Gambar 4. Diagram Alir untuk Modul Pemroses 


\section{MIKROKONTROLER}

Mikrokontroler adalah sebuah chip yang minimal terdiri dari CPU, non-volatile memory, volatile memory, timer dan unit pengontrol I/O. Mikrokontroler berfungsi untuk mengontrol sebagian/seluruh bagian dari sebuah alat elektronik/sistem untuk melakukan sebuah fungsi yang spesifik [7].

Modul pemroses menerima input dari modul pendeteksi ruang, modul tombol bantuan dan modul tombol reset. Hasil informasi dari sensor pendeteksi diolah oleh modul pemroses dan dikirimkan ke modul LED dan modul bluetooth. Hasil informasi dari modul tombol dikirimkan ke modul LED berupa kedipan. Diagram alir untuk modul pemroses dapat dilihat pada Gambar 4.

Modul pemroses ini diawali dengan inisialisasi lampu LED dan sensor di setiap ruang ganti. Sensor PIR yang mendeteksi adanya orang, maka lampu LED menyala dan data dikirim ke tampilan user interface melalui bluetooth. Apabila sensor PIR tidak mendeteksi adanya orang, maka LED tidak menyala dan tidak mengirimkan data apapun ke tampilan user interface melalui bluetooth. Apabila tombol bantuan ditekan, maka lampu LED akan berkedip. Apabila tombol reset ditekan, maka lampu LED berhenti berkedip.

Arduino Mega 2560 papan pengembangan mikrokontroller yang berbasis Arduino dengan menggunakan chip ATmega2560. Board ini memiliki pin I/O yang cukup banyak, sejumlah 54 buah digital I/O pin (15 pin diantaranya adalah PWM), 16 pin analog input, 4 pin UART (serial port hardware). Arduino Mega 2560 dilengkapi dengan sebuah oscillator $16 \mathrm{Mhz}$, sebuah port USB, power jack DC, ICSP header, dan tombol reset. Bentuk fisik Arduino Mega dapat dilihat pada Gambar 5.

\section{LIGHT-EMITTING DIODE (LED)}

Light-Emitting Diode (LED) digunakan sebagai penanda atau indikator pada ruang ganti yang ditujukan bagi pegawai. Ketika tombol bantuan ditekan LED akan berkedip yang menandakan bahwa customer dalam ruang ganti membutuhkan bantuan.

LED memiliki cara kerja dioda. LED hanya akan memancarkan cahaya apabila dialiri arus maju (bias forward) dari anoda menuju ke katoda. LED yang menyala menandakan bahwa ruang ganti sedang digunakan. LED yang berkedip menandakan customer butuh bantuan. LED yang tidak menyala menandakan ruang ganti sedang tidak digunakan. Skematik modul LED dapat dilihat pada Gambar 6.

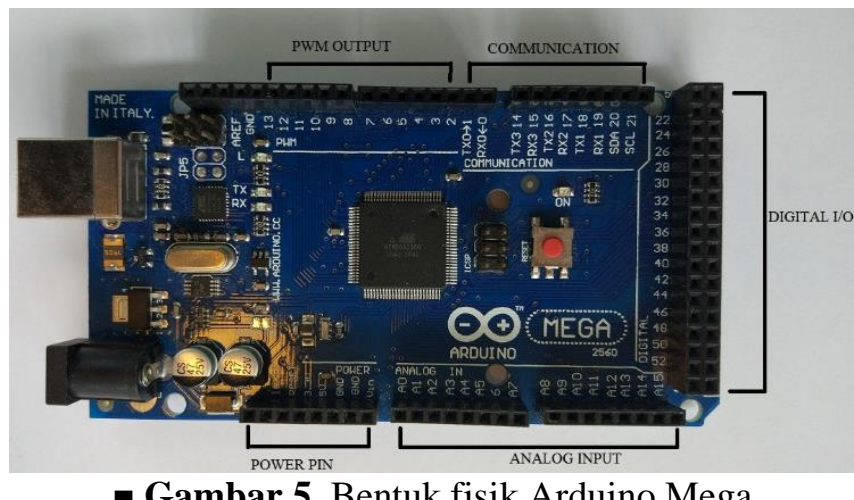

- Gambar 5. Bentuk fisik Arduino Mega

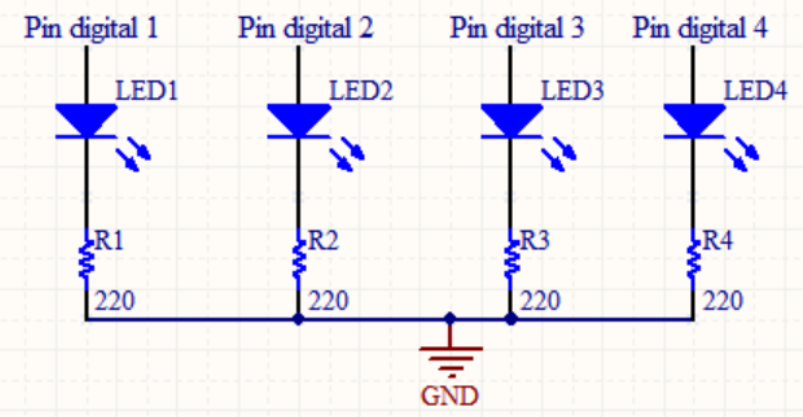

- Gambar 6. Skematik Modul LED 


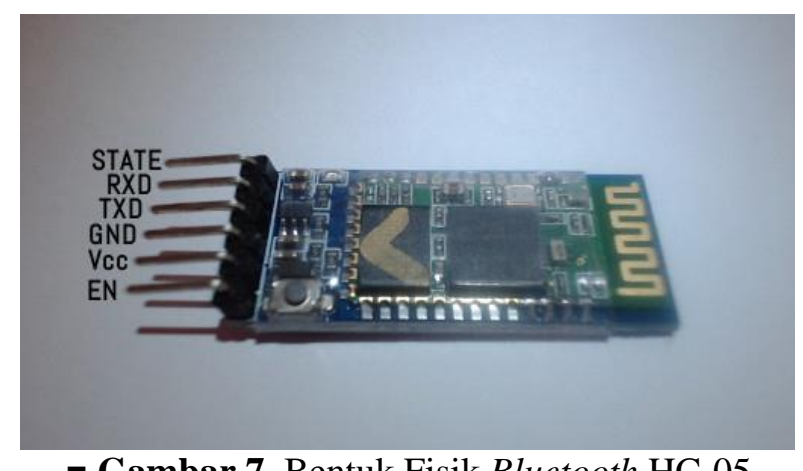

- Gambar 7. Bentuk Fisik Bluetooth HC-05

\section{BLUETOOTH HC-05}

Bluetooth adalah sebuah teknologi wireless yang mampu menyediakan layanan komunikasi data dan suara dengan jarak jangkauan yang terbatas. Bluetooth adalah sebuah teknologi komunikasi wireless (tanpa kabel) yang bekerja menggunakan frekuensi radio dan beroperasi pada frekuensi 2,4 GHz. Bluetooth diperkenalkan oleh Ericsson pada tahun 1994, untuk keperluan Mobile phone[8].

Bluetooth berfungsi untuk melakukan pengiriman data dari modul pemroses yang dikirim ke modul android. Fitur yang digunakan bluetooth adalah serial RXD, TXD, VCC, dan GND. Koneksi bluetooth yang terhubung dengan mikrokontroler terlihat pada indikator LED. Tegangan input yang digunakan antara 3,5V-6V DC. Bentuk fisik bluetooth dapat dilihat pada Gambar 7.

\section{SISTEM OPERASI ANDROID}

Android adalah sebuah sistem operasi berbasis linux yang dikembangkan oleh Google. Android bersifat open source yang membuat daya tarik untuk para pengembang aplikasi perangkat bergerak untuk mencoba menciptakan aplikasi [9]. Sistem operasi Android banyak digunakan untuk perangkat layar sentuh seperti smartphone, televisi pintar, komputer tablet.

Perangkat dan alat-alat masa kini sudah mulai menggunakan sistem operasi android. Sistem operasi Android dikembangkan dalam bahasa pemrograman Java dengan menggunakan Software Development Kit (SDK) Android. Android Studio menggunakan kombinasi Bahasa java dan Extensible Markup Language (XML). Pada tahun 2014, google menciptakan Android Studio sebagai aplikasi utama untuk pengembangan aplikasi android [10]. Sistem yang dirancang dalam penggunaannya terhubung dengan sebuah smartphone yang memiliki aplikasi yang dirancang. Sebuah smartphone secara khusus disediakan oleh pengelola department store. Smartphone diletakkan di depan ruang ganti agar pelanggan dapat melihat denah ruang ganti sebelum masuk ke dalamnya. Setiap pelanggan tidak perlu mengunduh aplikasi ruang ganti di department store ini, karena untuk mengetahui denah ruang ganti yang kosong dapat dilihat melalui smartphone khusus tersebut. Smartphone yang dapat terhubung dengan sistem adalah smartphone dengan operating system (OS) Android.

Diagram alir untuk penampilan pada android dapat dilihat pada Gambar 8. Sistem Android ini diawali dengan inisialisasi keadaan awal setiap ruang ganti dari ruang ganti 1 sampai ruang ganti 4 . Apabila ada orang dalam ruang ganti 1 maka input data yang diterima android adalah data 1. Apabila dalam ruang ganti 2 ada orang maka input data yang diterima oleh android adalah data 2 . Hal ini berlaku untuk ruang ganti 3 dan ruang ganti 4 jika ada orang dalam ruang ganti tersebut. 


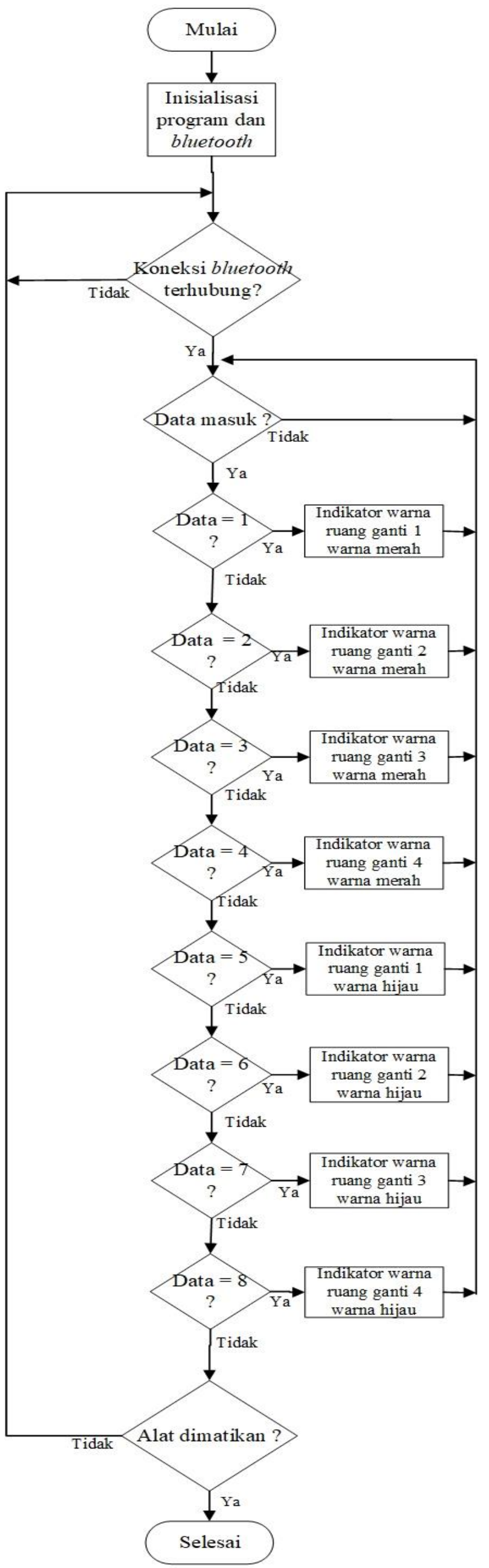


- Gambar 8. Diagram alir untuk penampilan pada android

Apabila dalam ruang ganti 1 tidak ada orang maka input yang diterima oleh android adalah data 5. Apabila dalam ruang ganti 2 tidak ada orang maka input yang diterima oleh android adalah data 6 . Hal ini berlaku untuk ruang ganti 3 dan ruang ganti 4 jika tidak ada orang dalam ruang ganti tersebut. Bentuk aplikasi android dapat dilihat pada Gambar 9. Tampilan android ketika ruang ganti sedang tidak digunakan berwarna hijau. Ketika ruang ganti sedang digunakan maka tampilan android berwarna merah.

$16: 05 * 0 \quad 0.00 \mathrm{~K} / \mathrm{s} \& \triangle \mathrm{TSEL} ; \triangle \mathrm{XL} 4 \mathrm{4G}$ (i) 23\%

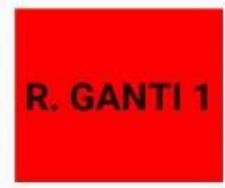

R. GANTI 2
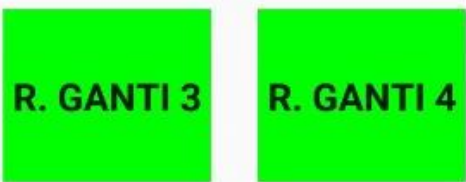

\section{VACANT}

\section{OCCUPIED}

- Gambar 9. Bentuk aplikasi android

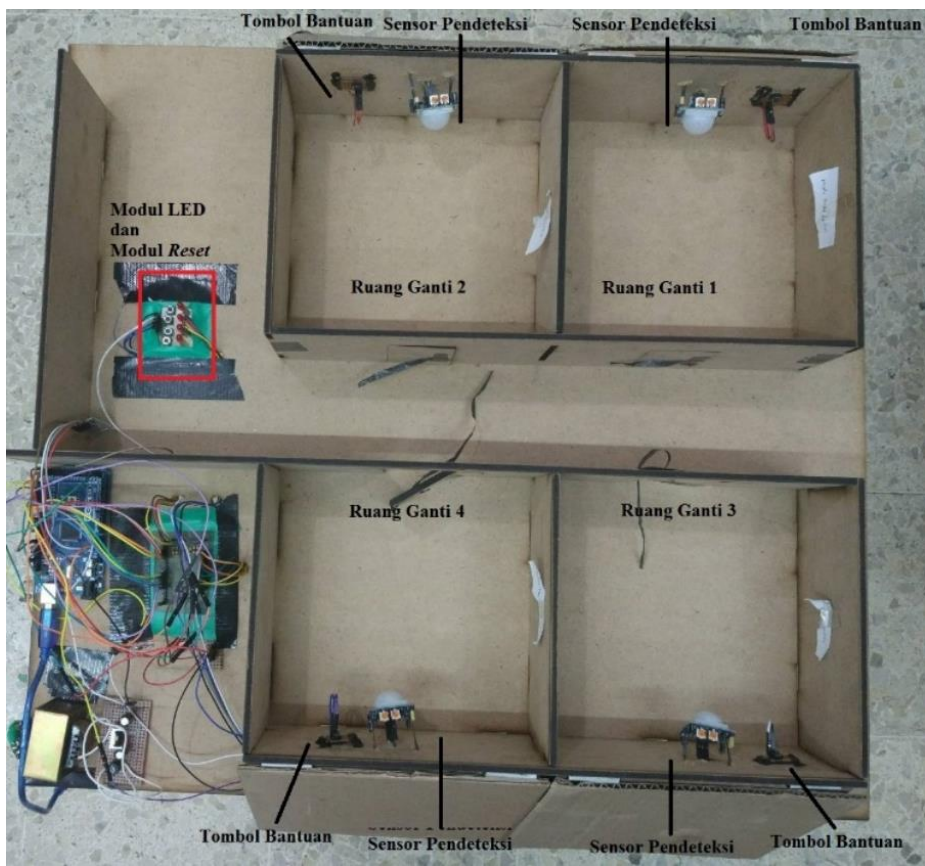

- Gambar 10. Rancangan Keseluruhan Berupa Sensor Pendeteksi di Setiap Ruangan, Tombol Bantuan, Tombol Reset, dan Modul LED 


\section{PENGUJIAN DAN ANALISIS KESELURUHAN TAMPILAN PENGANTRIAN PADA RUANG}

\section{GANTI}

Pengujian secara keseluruhan dilakukan dengan menghubungkan semua modul yang ada. Modul sensor, modul tombol, modul LED dan modul bluetooth dihubungkan ke modul pemroses. Rancangan keseluruhan berupa sensor pendeteksi di setiap ruangan, tombol bantuan, tombol reset, dan modul LED dapat dilihat pada Gambar 10.

Program android dioperasikan pada smartphone sebagai tampilan user interface. Tampilan user interface terhubung dengan pemroses melalui bluetooth. Hasil output dapat dilihat melalui tampilan user interface bersistem android dan modul LED. Tampilan user interface akan menampilkan kondisi sensor pada setiap ruang ganti. Jika tampilan user interface berwarna hijau menandakan ada orang pada ruang ganti. Jika tampilan user interface berwarna merah maka menandakan tidak ada orang pada ruang ganti.

Pengujian dilakukan sebanyak 12 kali dengan kondisi yang berbeda-beda. Kondisi sensor yaitu ada dan tidak ada orang. Modul LED akan menyala jika sensor mendeteksi adanya orang. Jika tombol bantuan ditekan, LED akan berkedip. Jika tombol reset ditekan, maka LED akan berhenti berkedip. Hasil pengujian secara keseluruhan pada pendeteksi ruang ganti dapat dilihat pada Tabel 1 . 


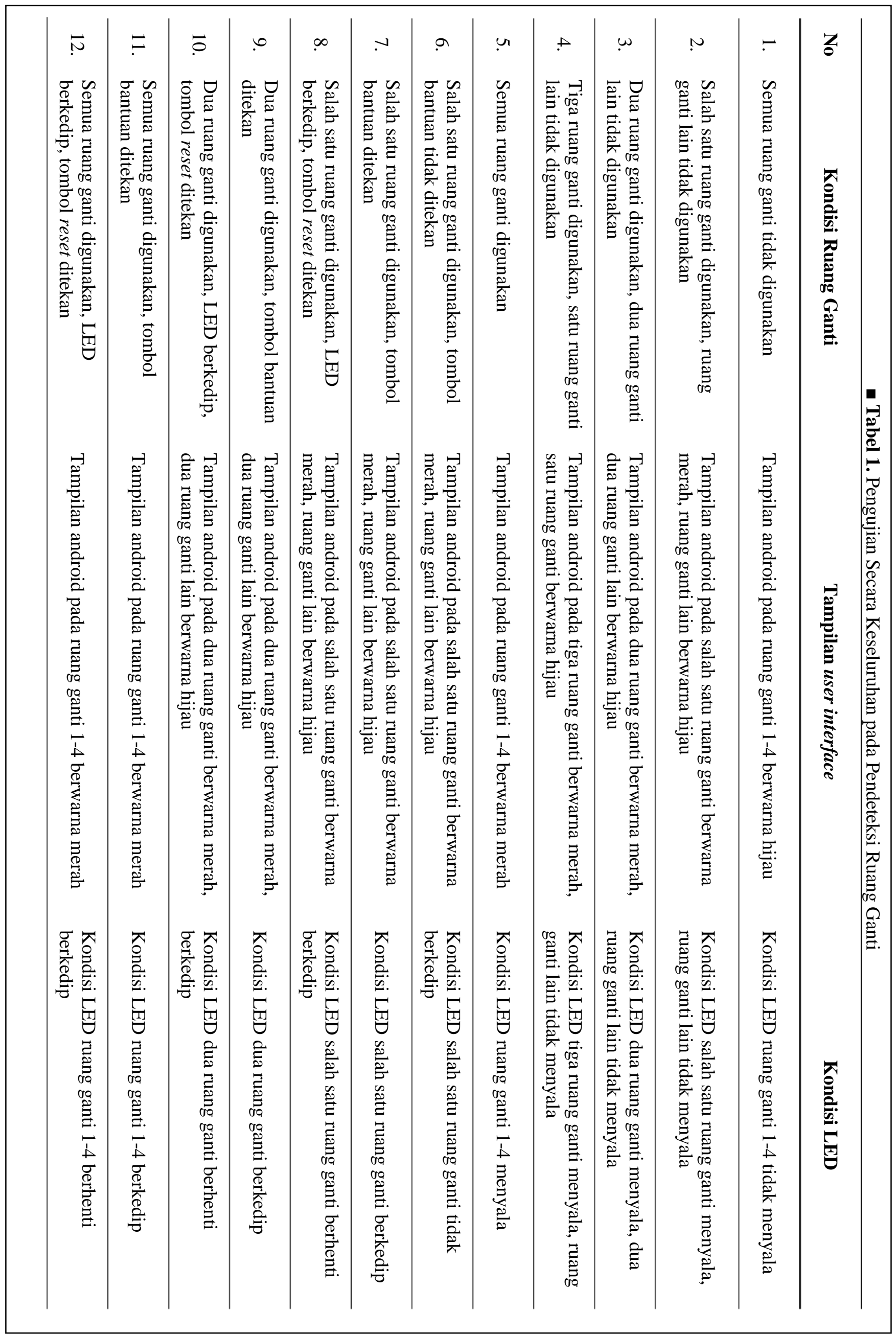




\section{KESIMPULAN}

Kesimpulan yang dapat diambil dari perancangan dan realisasi tampilan pengantrian pada penggunaan ruang ganti di department store

1. Sensor pendeteksi gerakan dapat digunakan untuk mendeteksi bahwa ruang ganti tersebut kosong atau terisi. Hal ini terlihat dengan terjadinya perubahan warna indikator hijau ketika sensor tidak mendeteksi ada gerakan dan warna indikator merah ketika PIR mendeteksi adanya gerakan.

2. Tombol bantuan ditekan dapat mengaktifkan LED untuk berkedip sebagai tanda bagi pramuniaga yang sedang bertugas di department store tersebut.

3. Tampilan user interface dari smartphone berbasis android dapat menerima informasi yang dideteksi oleh sensor dan LED melalui bluetooth.

\section{DAFTAR PUSTAKA}

[1] M. Kadek, Y. Laili, S. Rully, "Pengembangan Aplikasi Daftar Perencanaan Kegiatan Berbagi Pakai Sistem Operasi Android", Teknik Informatika Institut Teknologi Sepuluh Nopember, Jurnal Teknik Pomits Vol. 2 No. 2, Surabaya, 2013, Pp 1-2

[2] Murtiwiyati, L. Glenn, "Rancang Bangun Aplikasi Pembelajaran Budaya Indonesia Untuk Anak Sekolah Dasar Berbasis Android", Teknik Informatika Universitas Gunadarma, Jurnal Ilmiah KOMPUTASI Vol. 12 No. 2, Depok, Desember 2013, Pp 2-4

[3] S. Andri, "Alat Kendali Lampu Rumah Menggunakan Bluetooth Berbasis Android", STMIK PalComTech, Jurnal Teknologi Dan Informatika Vol. 4 No. 1, Januari 2014, Pp 3-7

[4] S. Muhammad, "Penyedia Catu Daya Cadangan Untuk Beban Listrik Rumah Tangga Secara Automatis", Jurnal Teknologi Academia Ista Vol. 11 No 1, Yogyakarta, Agustus 2006

[5] B. Vinodhini, K.Abinaya, R.Roja, M.Rajeshwari, "Wireless Two-way Restaurant Ordering System via Touch Screen", The International Journal Of Engineering And Science (IJES) Vol. 3, 2014, pp. 1-3.

[6] D. Nataliana, I. Syamsu, G. Giantara," Sistem Monitoring Parkir Mobil menggunakan Sensor Infrared berbasis RASPBERRY PI", Teknik Elektro Itenas, Jurnal ElKOMIKA Vol. 2 No.1, Bandung, 2014, pp. 12

[7] D. Rusmandi, "Pengetahuan Dasar Elektronika", Penerbit Sinar Baru, Bandung, 2007

[8] A. Andi, H. Oka, "Rancang Bangun Prototipe Elevator Menggunakan Microcontroller Arduino Atmega 328P”, Teknik Elektro Universitas Mercubuana, Jurnal Teknik Elektro Vol. 4 No. 3, Jakarta, September 2013, Pp 4

[9] L. John, "PIC Robotics", The Mcgraw-Hill, 2004, Pp 1-2

[10] P. Rahadhian, K. Rosadi, "Sensor Parkir Mobil Berbasi Mikrokontroler AT89S51 Dengan Bantuan Mini Kamera", STMIK jakarta STI\&K, Jurnal Komputasi Vol. 11 No. 1, Juni 2012, Pp 4-5 